\title{
A Precious Bequest: Contemporary Research with the WPA-CCC Collections from Moundville, Alabama*
}

\author{
CHRISTOPHER S. PEEBLES $\dagger$ \\ Museum of Anthropology \\ University of Michigan \\ Ann Arbor, Michigan 48109 \\ Department of Anthropology \\ University of Alabama \\ University. Alabama 35486
}

\section{MARGARET J. SCHOENINGER \\ Department of Anatomy and Cell Biology \\ The Johns Hopkins University \\ Baltimore, Maryland 21238}

\section{VINCAS P. STEPONAITIS}

Department of Anthropology

State University of New York

Binghamton, New York 13901
C. MARGARET SCARRY Museum of Anthropology University of Michigan Ann Arbor, Michigan 48109

$\mathrm{M}$ oundille, which archaeologist James Brown called the New York City of 15th-century North America, was the geographic, political, and symbolic center of Native American life in the Black Warrior River Valley between A.D. 1250 and 1500. Today, this site has become a major focus of research on the development, maintenance, and decline of complex societies in the southeastern United States. Part of Moundville's contemporary importance stems from its size and the diversity of its archaeological remains. It is the second largest Mississippian ceremonial center in the eastern United States and comprises 20 major platform mounds and a 30 ha plaza. Additional value comes from its

- The major funds for this project were provided by the National Science Foundation (GS-2837, BNS 78-07133-01 to C.S. Peebles and BNS 80-07130 to C. Margaret Scarry).

$\dagger$ Current address: Department of Anthropology. Northwestern University, Evanston, IL 60201.

$\ddagger$ To whom reprint requests should be addressed. 
remarkable state of preservation. Moundville, and the other sites of the Moundville phase, have been protected from vandalism, and generally have been immune from the effects of other destructive forces. Moundville's greatest measure of significance, however, does not come from what is preserved in the ground - not that these deposits are an unimportant resource-but from a series of remarkable excavations undertaken between 1840 and 1941. In this 100 year span, an unbroken line of scholars built upon each other's work to produce one of the largest and best documented collections of material thus far excavated in the Southeast. The most extensive of these projects, conducted between 1929 and 1941, encompassed almost one-half million square feet of the site. The vast majority of the materials from all these excavations, and especially those from the later project, were neither analyzed nor described in publications, and only one-quarter of these data were presented in a public forum of any kind. The spectacular artifacts were put on display, but the remainder of the materials and the records were accessioned, catalogued, and put into storage.

These collections, distributed from Boston to Tuscaloosa, from Chicago to New York, and lodged at a few points in between, have been the touchstone of our research for the last 13 years. During this period, the records of the 1929 to 1941 excavations have been reconstructed, and a basic site report has been written. Gaps in the records and collections have been filled by other sources and by judicious new excavations. A ceramic chronology has been constructed, basic models of social and economic organization have been created, and fundamental aspects of the subsistence system have been drawn with some precision. These adaptative dimensions have been cast in the framework of individual diet and general measures of population size and health.

This paper will be concerned with the path-better the maze-from dusty pots wrapped in depression-era ("eggs $8 \subset$ dozen") newspapers and foxed, musty records, to chronology, economy, and society. In this narrative, particular attention will be devoted to the inevitable problems that got buried in even the most rigorous and detailed sets of field and laboratory records. These problems underscore the fact that those of us who work with museum collections are removed yet one more step from the indivudals who created the archaeological record. Not only do we deal with durable items and their patterns of manufacture, distribution, use, discard, deposition, and destruction, ${ }^{26}$ but we have to confront and translate patterns of archaeological excavation, description, preservation, and curation several generations removed from our own. 


\section{CREATION OF THE MOUNDVILLE COLLECTIONS}

Fieldwork at Moundville has spanned the period from 1840 to the present. Excavations were conducted there for brief periods in 1840 and 1869, for several weeks each in 1905 and 1906, almost continuously from 1929 to 1941, intermittently between 1948 and 1951, and by field schools throughout the 1970s. As might be expected, the field techniques employed by these projects, as well as their scope and intensity, varied markedly through the years.

From the beginning, some form of association was recorded between burials and their grave goods, and most major finds were described in relation to the area of the site from which they were taken. It was not until 1932, however, that a grid system was used in any form to control excavations at Moundville. Major stratigraphic units were noted in the mound profiles, but in most cases these were in the form of verbal descriptions rather than profile drawings. Few excavations recognized stratification in the other areas of the site. The notion of just what constituted archaeological "data" gained breadth and depth over the 140 years of fieldwork. Whole artifacts and burials were regarded as important from the first, but the skeletal remains themselves were not saved routinely until after 1929. Archaeological features, apart from the burials, were not regarded as either crucial archaeological units or important contextual elements until after 1932. Sherds were not considered to be data until 1932, and lithic debitage was not saved until very recently. Floral and faunal materials, apart from large animal bones and pits densely packed with carbonized cane and corn, were neither sought nor saved.

The cumulative effects of the evolution of field techniques on archaeology at Moundville were: (1) better spatial and contextual control; (2) greater variety in the number and quality of observations; (3) finer recovery techniques. By 1978, microstratigraphic controls were used routinely, three-dimensional "piece-plotting" of certain artifacts was employed, a sample of all deposits was processed through a flotation device, and the remainder of the matrix was passed through a fine-mesh water screen. The techniques of interest here, however, are those which were employed to create the collections between 1840 and 1941, during the formative phase of research at Moundville.

There must always be a first, and Thomas Maxwell12 was the first on record to excavate at Moundville. In 1840, he dug into the largest mound, Mound B, and noted daub and sherds in the fill. For the next 36 
years, Maxwell chronicled the recovery of artifacts and burials that washed out of the site after plowing and heavy rains. In 1876, as part of a monograph that passionately defended spelling Tuscaloosa with a $k$, he presented a detailed discussion of west Alabama prehistory and described many of the artifacts recovered at Moundville. These descriptions are doubly important because they serve to authenticate materials in the collections of the Harvard Peabody and Field Museums.

Nathaniel T. Lupton was the next to excavate at Moundville and leave a written record. Lupton was a man of many talents: scholar, chemist, professor, executive in the Government of the Confederate States of America, and President of the University of Alabama. ${ }^{25}$ In 1869 Joseph Henry, Secretary of the Smithsonian Institution asked Professor Lupton to explore the mounds near Carthage (Moundville), Alabama. Lupton made an accurate map of the mounds and plaza complex and traced the course of the earthworks south of the site. He excavated a trench in Mound $O$ and described the deposits with sufficient accuracy and detail for a contemporary reconstruction of the building stages. ${ }^{28}$ Lupton's notes and collections were sent to the Smithsonian where they are curated today. Lupton's work showed that despite local folk tales of mounds being destroyed, only the 20 mounds that exist today were present in the past. Moreover, his map is the only accurate record of the location of fortifications along the southern margins of the site.

Lupton was not the only Smithsonian archaeologist to work at Moundville. In 1882, James D. Middleton was sent to Moundville by Cyrus Thomas, director of the Mound Exploration Division. Middleton's work was far below the standards set by Lupton. His map is confused and his notes are lacking in detailed observations about the site. ${ }^{28}$ Middleton's brief trip marked the start of a 25-year hiatus in organized archaeological work at Moundville.

Clarence B. Moore, who probably excavated at more sites in the Southeast than any other single archaeologist, ${ }^{29}$ tied his steam yacht Gopher at Prince's Landing, Moundville, Alabama for the first time in the spring of 1905. He and his crew spent one month at Moundville that year and returned again for one month in $1906 .{ }^{14,15}$ During these 2 months, Moore put "trial holes" in most of the mounds and in many other parts of the site. Although his field techniques were primitive by today's standards, in 1905 they were a model of excellence in the Southeast. He made a very accurate map of the site and described the approximate locations of his excavation units in relation to that map. The focus of Moore's work was on graves that contained artifacts. He record- 
ed each of 801 graves and its associated grave goods as a unit and saved some of the skeletal material. Most important, he published lightly edited versions of his detailed field notes and included therein illustrations of most of the several hundred complete pottery vessels, and the several score of copper, shell, and stone artifacts he found.

Moore's collection and notes initially were curated by the Academy of Natural Sciences of Philadelphia. They were transferred to the Museum of the American Indian in the 1920s where they are today. At some point between excavation and final cataloguing, Moore's Moundville collection was "high-graded." 28 The undecorated whole vessels and the sherds either were discarded or were given to another museum. The skeletal collection was deaccessioned, dispersed, and the Moundville burials may have been destroyed. What remains are the spectacular artifacts and the notes, and these materials are curated professionally and are readily available for study.

The University of Alabama has maintained an active interest in Moundville since Lupton's work there in 1869. Eugene Alan Smith, State Geologist, founder and Director of the Albama Museum of Natural History, and Professor of Geology ${ }^{25}$ was Lupton's good friend and colleague. During Lupton's presidency of the University (1871-1874), they took many field trips together. Smith's interest in Moundville was continued by his student, colleague, and in 1927, successor, Walter B. Jones. Jones, in turn, inducted a young electrical engineer and natural scientist, David Lloyd DeJarnette into the group of Moundville scholars in 1929. These three men form an unbroken intellectual chain that extends from the first work at Moundville to today.

When Waiter B. Jones became Director of the Alabama Museum of Natural History in 1927, he began to fulfill a life-long dream he had shared with Smith: to bring Moundville into public ownership and to conserve it. No less a scholar than Moore had urged such a step in 1910 when he had written to Peter Brannon, Secretary of the Alabama Anthropological Society and Director of the Alabama State Archives: "The time will come when the State of Alabama will regret not having purchased and preserved these wonderful monuments. ${ }^{16}$ In addition, Jones wanted to show that despite Moore's claims to the contrary, the site had not been explored completely.

In 1929, with funds supplied by public subscription, the Alabama Museum of Natural History bought 135 acres of the site from the Griffin estate. Over the next few years as land became available, it too was bought. ${ }^{8}$ When funds were short and land was on the market, Jones 
mortgaged his house to get the money to buy it. ${ }^{30}$ During the period 1929 to 1932, as land was bought, archaeological test excavations were made in the newly acquired parcels. These excavations showed that the site was far more extensive than Moore had imagined and that, as Jones told Peebles, with a small chuckle added for emphasis, "Moore had not milked the site dry."

David DeJarnette was put in charge of the excavations from their inception. The techniques employed for these excavations between 1929 and 1932 were essentially an extension of those used by Moore 25 years earlier. Graves were located and excavated, and notes were kept on grave locations and associations. In 1932, David DeJarnette enrolled in the University of Chicago archaeological field school taught by FayCooper Cole. Upon his return to Alabama, the archaeological techniques used at Moundville changed radically. Soil stains and depositional sequences were recorded; features other than burials were sought, recognized, excavated, and recorded; a grid system (Chicago-style left and right designations plus centerline) was employed; and, for the first time, sherds were saved. ${ }^{19}$

By the mid-1930s, the work at Moundville-like so much of the archaeological research in the Southeast - had come under the sponsorship of the Emergency Work Conservation Program. David DeJarnette was joined over the next few years by his brothers James and Tom DeJarnette, Steve Wimberly, and Maurice Goldsmith to form the supervisory archaeological staff; Walter $B$. Jones continued as director of this project as well as the force behind other archaeological research in the Southeast. By the time the threat of World War halted the work in 1941, almost one-half million square feet (ca. $45,000 \mathrm{~m}^{2}$ ) had been excavated. Over 75 structure patterns had been recorded, more than 2250 burials had been recovered, and over 200,000 artifacts had been catalogued.

During World War II Mr. E. H. Chapman, a precise and patient man, gradually checked the catalogue against the actual inventory of items and moved the Moundville collections into storage. There they remained to await better days.

In summary, the early work at Moundville firmly established the number and location of the mounds, located the line of fortifications south of the site, and established the authenticity of several artifacts that later came into museum collections. Moore's excavations, which to this day comprise the only major source of data for the contents of the mounds, provided a diverse sample of all areas of the site. The Alabama Museum of Natural History excavations during the 1930s produced a 
major, well-excavated, copiously documented collection that encompassed 14 percent of the most intensely occupied portions of the site and of 4 percent of the site as a whole. When Moore's work is added to these figures, the total area excavated rises to 15 percent and 5 percent, respectively.

Moore's work had provided the only major source of descriptive information for Moundville, and his publications have been cited widely and frequently for over 75 years. The conceptual framework for research at Moundville, however, came from Jones and David DeJarnette. They recognized a distinctive "Moundville Culture" from the beginning of their work. ${ }^{8}$ This informal cultural-historical construct was given formal definition by David DeJarnette and Steve Wimberly in 1941 when they included the Moundville and Bessemer sites in an unnamed aspect of the Mississippian Pattern. ${ }^{5}$

Unfortunately, the war had the same effect on analysis of the data that it had on the fieldwork: it brought it to a halt. After the war, the economy, which was again healthy, turned to houses, cars, and consumer goods, not to archaeology. The archaeologists who were mustered out of the service turned to teaching and curation rather than fieldwork. Ideas that had fermented and matured for more than 5 years in New Guinea, North Africa, and Alaska finally were written up and published. These publications, however, were not site reports, for which there were no funds, but distillates of the observations and insights from a decade of fieldwork. Immediately after the war, David DeJarnette wrote two basic syntheses of Alabama's prehistory. ${ }^{3.4}$ Shortly thereafter, he was appointed the first curator of the Museum of Atomic Energy. He returned to Moundville as curator of Mound State Monument in 1951, and he spent the next 25 years conserving the collections, building the museum's exhibits, and training a significant number of the archaeologists that work in the Southeast today.

\section{RESEARCH WITH THE MOUNDVILLE COLLECTIONS:}

$$
1963 \text { TO } 1976
$$

The first person to work extensively with the Moundville collections who was not directly connected with their excavation was Douglas $H$. McKenzie, a graduate student at Harvard University. During 1963, he spent 6 weeks each at Moundville and at the Museum of the American Indian. One part of his dissertation, which was based on an analysis of these collections, defined the Moundville phase. Subsequent research has 
shown that his cultural-historical judgments were generally correct. His failure to master the excavation records, however, led to several fundamental problems in his work. McKenzie suggested that the 500 whole ceramic vessels in his sample were all that had been recovered from the site. ${ }^{11}$ In fact, Moore listed 342 vessels in his notes, and 162 of this number are included in the Museum of the American Indian collection; the Alabama Museum of Natural History catalogue showed that approximately 1400 of these vessels were recovered between 1929 and 1941, and approximately 1100 of these have been verified in their collection today..$^{28}$ Similar problems can be found in his analyis of the features from Moundville. It was clear from the problems that beset McKenzie's research that any future use of the Moundville collections would depend first on the reconstruction of the field notes and records from the Alabama Museum of Natural History's excavations.

The extent and complexity of these materials turned out to be staggering: two filing cabinets of primary field notes, two more of essential records and reports, and several more of administrative records and photographs. These thousands of pages of observations evidenced an internal logic, a system of acronyms and designations, and an evolutionary history all their own. Their reconstruction required not only a translation of their "grammar," but an understanding of what was and was not recorded at any given point in the 11 years during which the field techniques evolved. For example, in the early excavation plans, postmolds were not recorded because they were not "seen"; in later plans, every soil stain was recorded as a postmold, and it was hard to sort out the pseudomolds from the postmolds.

The only major flaw in the Alabama Museum of Natural History excavations was the lack of a master grid system for the site. Each excavation had a separate, free-floating grid, the most complex of which followed the $2 \mathrm{~km}$-long centerline of a roadway that encircled the plaza. In order to tie these various grid systems together and to locate them on the site as a whole, aerial photographs taken on the site between 1931 and 1941, still photographs with landmarks such as mounds and buildings in their background, and a scale model of the site were employed. Excavation units were shifted around on the surface of this model until the topographic, photographic, and other clues matched. It took one year of full-time work to produce the master map of the excavations, and 3 additional years to write a basic site report. ${ }^{19}$

The re-creation of the archaeological context for the Moundville collection had a number of immediate benefits, not the least of which was 


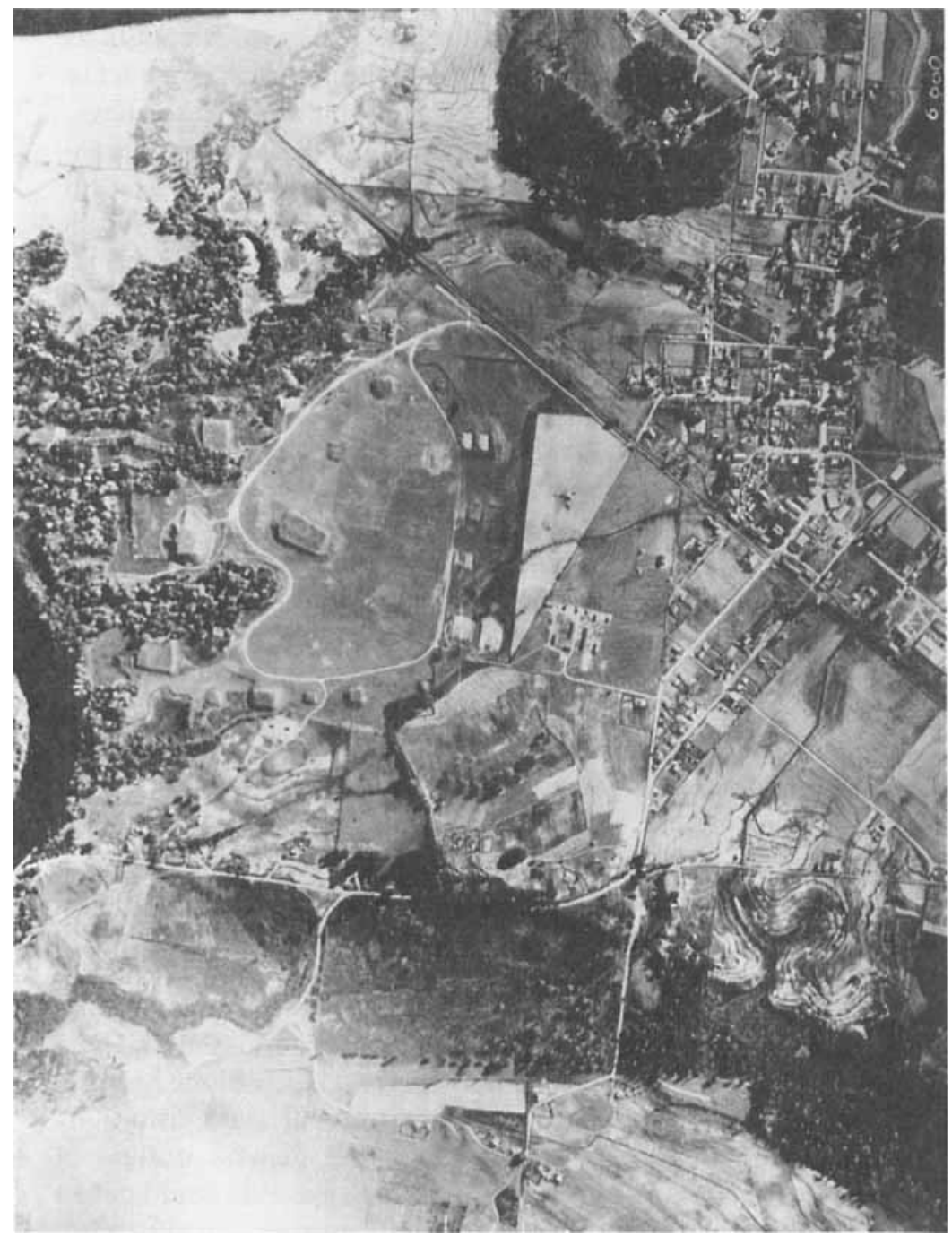

壳 壳 总 它出 5 突

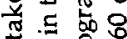
ज吃 ๙ 교

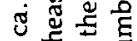

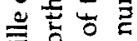

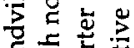

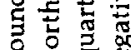
을 원

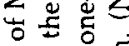
充吾岁 군응 옹

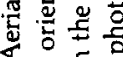
$<$ 동

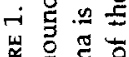
岁 点边告 
that it provided a wealth of high quality data for analysis. First, an analysis of approximately 2000 burials and their associated grave goods confirmed the results of an earlier study ${ }^{17}$ based on data from Moore's publications. It pointed to the existence of two distinct social strata in the Moundville population. There was an "elite" stratum, which comprised approximately 5 percent of the population, within which spectacular grave goods and elaborate mortuary ritual cross-cut age and sex lines. This pattern suggested that high rank was based on birth rather than age, sex, and the accomplishments of a lifetime. There was a second stratum, which contained the remaining 95 percent of the population, within which grave goods and mortuary ritual closely paralleled age and sex divisions. This pattern suggested that social rank was dependent on the "givens" of age and sex and on the achievements that were part of an individual's life history. ${ }^{21}$ Second, the distribution of artifacts and features pointed to the fact that Moundville was not only arranged into mound, plaza, and settlement precincts, but that there were areas characterized by "public" buildings, areas characterized by industrial activities, and areas that seem to have been used for the "chunkee" game. Third, the distribution of the other Moundville Phase sites in the Black Warrior River Valley seemed to be conditioned by both cultural and natural factors. The gross size of the agricultural villages and hamlets that made up the Moundville phase appeared to be regulated by the productivity of nearby soils. ${ }^{18}$ The locations of the single-mound, minor ceremonial centers seemed to have been chosen to minimize the costs in the flow of goods and information to Moundville. ${ }^{27}$

These initial explorations in the Moundville collections and records were exciting and productive. It was as though with a little imagination and the site plans in hand one could take a tour of prehistoric Moundville. Every new excavation, every new feature examined, served to change the mental picture being constructed of the site. This work, however, produced more new questions than answers. It pointed to major imperfections and shortcomings in our knowledge, and it highlighted several gaps in the data. The approximate temporal limits of the Moundville phase were known, but there were no internal subdivisions by which change could be measured. Although the general outline of Moundville's subsistence system could be sketched, specifics could not be adduced because there were few floral and faunal materials in the collections. There was little information on other Moundville phase sites in the Black Warrior River Valley aside from their approximate sizes and locations. The social and settlement models constructed to that point could 
have been chimerical houses of cards, but each had test implications that could be checked with additional analyses.

These gaps, problems, and questions led to a research proposal that would plug, solve, and perhaps answer a few of them. We proposed the construction of an internal ceramic chronology supported by radiocarbon dates for the Moundville phase. We planned limited excavations at Moundville to recover a sample of floral and faunal material and to produce a stratified sample of ceramics with which to cross-check the seriation. We designed a survey and testing program to gather basic information about the other Moundville phase sites in the Black Warrior River Valley. We refined the laboratory techniques and selected bone samples to examine the dietary correlates of social ranking. The National Science Foundation granted funds in April, 1977 (BNS 78-07133-01), and we completed most of the field and laboratory work in December, 1980. The remainder of this paper will sketch some of our preliminary results.

\section{RESEARCH AT MOUNDVILLE: 1977 TO 1981}

The first and most fundamental task was the construction of a reasonably fine-scale ceramic chronology. As a group, the distinctive Moundville phase ceramics had been included in the Middle Misissippian tradition, ${ }^{6}$ and cross-dating implied a temporal span from A.D. 1100 to 1500. Given what was known plus the large sample of whole vessels from secure contexts, the only choices that had to be made were the attributes, measures, and numerical techniques to be used in a seriation. The attributes selected were type-variety designations plus secondary shape features that cross-cut these types and varieties. The measure selected was a distance function for presence-absence attributes devised by Cowgill. ${ }^{2}$ The numerical technique chosen was non-metric multidimensional scaling, Lingoes' MINISSA programs. ${ }^{10}$ The sample comprised 87 gravelots that contained two or more chronologically sensitive attributes among their assemblages. ${ }^{28}$

The results of the seriation indicated that the Moundville phase could be divided into three major periods or subphases, and that, in turn, the later two divisions could be broken down further into early and late segments. ${ }^{28}$ The order implied by the seriation was supported by the ceramic sequence from two stratigraphically controlled test units and was anchored at its early end by several radiocarbon dates. When the preceding Early Mississippian, West Jefferson phase and subsequent protohistoric Alabama River phase are added, an 800-year-long ceramic 
chronology can be constructed: West Jefferson, A.D. 900-1050; Moundville I, A.D. 1050-1250; Moundville II (early and late), A.D. 1250-1400; Moundville III (early and late), A.D. 1400-1550; and Alabama River, A.D. $1550-1700 .^{28}$

When the burials and other features with diagnostic ceramics are assigned to one of the several chronological divisions and then plotted on a map of Moundville by period, the growth and decline of the site can be charted. Moundville began as a village in the West Jefferson phase. In the subsequent Moundville I phase, it consisted of one truncated pyramidal mound, perhaps one low, round burial mound, and a residential area. It reached its maximum extent of 150 ha and 20 mounds sometime during the Moundville II period and maintained this size through the Moundville III period. In the protohistoric, Alabama River phase, Moundville declined in size to that of a small village once again. ${ }^{28}$

The analysis of the Moundville ceramics yielded several additional dividends. The geographic origin of the imported ceramic vessels indicated exchange networks that reached to the northwest as far as Spiro, Oklahoma, west into the Lower Mississippi valley, south to the Gulf Coast, and north into the Tennessee-Cumberland region. None of the imported ceramics had their origin either in the Appalachian Mississippian, in the Etowah sequence, or in the upper Chattahoochee valley to the east.

The locally manufactured ceramics show the development of two ceramic traditions: one, coarse wares; the other, fine wares. The coarse ware vessels were probably made by coiling and then either scraping or compacting with a hammer and anvil. The majority of these vessels were not decorated. Vessels in the fine ware tradition were made by coiling with the aid of a rest and later by coiling in a mold. Many of these vessels were engraved, and preliminary analysis suggests that there may have been a limited number of specialists who decorated these vessels. ${ }^{9,7}$

The preliminary analysis of the site survey data in conjunction with the framework provided by the ceramic chronology has given a developmental dimension to the Moundville phase settlement system in the Black Warrior River Valley. The early Moundville I single mound centers seem to have been located in areas that had large West Jefferson populations. During Moundville II and III, the single mound centers probably served to integrate a population dispersed in hamlets and villages. The single mound centers ceased to be foci of dispersed populations in the Alabama River phase, and at some point during late Moundville III 
or the Alabama River phase, the population was concentrated in large villages. ${ }^{1,20,28}$

The four test excavations at Moundville yielded not only stratified ceramic samples but also abundant floral and faunal remains. The greatest part of the deposits in the two $2 \times 2 \times 2 \mathrm{~m}$ and two shallow 1 $\times 1 \mathrm{~m}$ units could be assigned to the Moundville I period on the basis of ceramics and radiocarbon dates. ${ }^{22}$ The preliminary analysis of the plant material from the Moundville I levels showed that agricultural intensification was complete by the early part of this period. Corn dominated the assemblage; squash, beans, and sunflower were present as well. ${ }^{23}$ The faunal remains, in order of abundance and weight of meat, comprised white-tail deer, turkey, and grey squirrel. Fish were present in all samples, and the most frequent species were drum and catfish. ${ }^{13}$

An analysis of the trace element composition of human bone provided an alternate means for the analysis of diet. A sample of bone has been drawn from 580 burials, and trace element analysis by neutron activation and atomic absorption spectrophotometry has been completed for 114 and 54 of these individuals, respectively. One of the dietary implications of social ranking was that the elite stratum would have more meat in their diet than the remainder of the population. The amount of strontium in bone mineral, given proper controls, is a good measure of the amount of meat in an individual's diet: the less strontium, the more meat. The difference in strontium between adult elite burials $(n=6, x=607, s$ $=225$ ) and other burials $(\mathrm{n}=26, \mathrm{x}=718, \mathrm{~s}=245)$, although not statistically significant, is in the direction predicted. As the number of samples is increased, the difference should become statistically significant. ${ }^{24}$

\section{RETROSPECT AND PROSPECT}

The Moundville collections are indeed a precious bequest. It would take several million dollars and several decades of fieldwork to duplicate them today. Instead, these collections have been conserved, and the reconstruction of the records plus limited fieldwork served to bring them to the point where they were of contemporary scholarly relevance. A small amount of work amplified their value manyfold. It should be apparent that we have exploited only a small part of the potential offered by these collections. We are building the framework today; the rich detail will come-we hope - with subsequent phases of our research. 


\section{ACKNOWLEDGMENTS}

We owe many thanks to the remaining partners in the Moundville Arcaheological Project: P. Welch, T. K. Bozeman, M. Hardin, and S. E. Van der Leeuw. They are the source of many of the ideas expressed here. Our work at Moundville would not have been possible without the aid and cooperation of the University of Alabama. Special thanks are due Drs, R. Krause and J. Vogel, C. Oakley, C. B. Curren, Jr., N. Jenkins, and L. Alexander. Finally, without the skill and vision of David Lloyd DeJarnette, none of this research would have been possible. He gave us a rich intellectual heritage upon which to build.

\section{REFERENCES}

1. BozEMAN, T.K. 1981. Moundville phase sites in the Black Warrior River valley, Alabama: preliminary results of the UMMA survey. Southeastern Archaeological Conference Bulletin 24: In press.

2. Cowgill, G.L. 1972. Models, methods and techniques for seriation. In Models in Archaeology. D.L. Clarke, Ed.:380-424. Methuen. London.

3. DeJarnetTe, D.L. 1947. A review of Alabama archaeology. Journal of the Alabama Academy of Sciences 19: 19-23.

4. DeJarnette, D.L. 1952. Alabama archaeology: A summary. In Archaeology of Eastern United States. J.B. Griffin, Ed.: 272-284. University of Chicago Press. Chicago, IL.

5. Dejarnette, D.L. S.B. Wimberly. 1941. The Bessemer Site: Excavation of Three Mounds and Surrounding Village Areas near Bessemer, Alabama. Geological Survey of Alabama, Museum Paper 17.

6. Griffin, J.B. 1967. Eastern North American archaeology: A summary. Science 156: 175-191.

7. HARDIN, M.A. 1981. The identification of individual style on Moundville engraved vessels: A preliminary note. Southeastern Archaeological Conference Bulletin 24: In press. 8. Jones, W.B. \& D.L. Dejarnette. no date. Moundville culture and burial museum. Geological Survey of Alabama, Museum Paper 13: 1-8.

9. VAN DeR Leeuw, S.E. 1981. Preliminary report on the analysis of Moundville phase ceramic technology. Southeastern Archaeological Conference Bulletin 24. In press.

10. Lingoes, J.C. 1973. The Gutman-Lingoes Nonmetric Program Series. Mathesis Press. Ann Arbor, MI.

11. McKenziE, D.H. 1966. A summary of the Moundville phase. Journal of Alabama Archaeology 12(1): 1-58.

12. Maxwell, T.H. 1876. Tuskaloosa: The Origin of Its Name, Its History, etc. Alabama Historical Society. Tuscaloosa, AL.

13. Michats, L. 1981. The exploitation of fauna during the Moundville I phase at Moundville. Southeastern Archaeological Conference Bulletin 24: In press.

14. Moore, C.B. 1905. Certain aboriginal remains of the Black Warrior River. Journal of the Academy of Natural Science, Philadelphia. 13: 123-224.

15. Moore, C.B. 1907. Moundville Revisited. Journal of the Academy of Natural Science, Philadelphia. 13: 337-405.

16. Owen, T.M. 1910. Handbook of the Alabama Anthropological Society. Montgomery, AL. 
17. Peebles, C.S. 1971. Moundville and surrounding sites: Some structural considerations of mortuary practices II. Society for American Archaeology Memoir 25: 68-91.

18. Peebles, C.S. 1978. Determinants of settlement size and location in the Moundville phase. In Mississippian Settlement Patterns. B.D. Smith, Ed.: 369-416. Academic Press. New York.

19. Peebles, C.S. 1979. Excavations at Moundville: 1905-1951. University of Michigan Press. Ann Arbor, MI.

20. Peebles, C.S. 1981. Moundville: Late prehistoric sociopolitical organization in the Southeastern United States. Proceedings of the American Ethnological Society. In press.

21. Peebles, C.S. \& S.M. Kus. 1977. Some archaeological correlates of ranked societies. American Antiquity 42: 421-448.

22. SCARry, C.M. 1981. The University of Michigan Moundville excavations: 1978-1979. Southeastern Archaeological Conference Bulletin 24: In press.

23. SCARry, C.M. 1981. Plant procurement strategies in the West Jefferson and Moundville I phases. Southeastern Archaeological Conference Bulletin 24: In press.

24. Schoeninger, M.J. \& C.S. Peebles. 1981. Notes on the relationship between social status and diet at Moundville. Southeastern Archaeological Conference Bulletin 24: In press.

25. Sellers, J.B. 1953. History of the University of Alabama, Volume One, 1818-1902. University of Alabama Press. University, AL.

26. Schiffer, M.B. 1976. Behavioral Archaeology. Academic Press. New York.

27. Steponaitis, V. 1978. Location theory and complex chiefdoms: A Mississippian example. In Mississippian Settlement Patterns. B.D. Smith, Ed.: 417-453. Academic Press. New York.

28. Steponaitrs, V. 1980. Ceramics, Chronology, and Community Patterns at Moundville, a Late Prehistoric Site in Alabama. Ph.D. dissertation. University of Michigan. Ann Arbor, MI.

29. Thomas, D.H. 1979. Archaeology. Holt, Rinehart, and Winston. New York.

30. Walthall, J.A. 1977. An Introduction to the Archaeology of a Mississippian Chiefdom. Alabama Museum of Natural History. University, AL. 